Article

\title{
Biocatalysis of D,L-Peptide Nanofibrillar Hydrogel
}

\author{
Tiziano Carlomagno ${ }^{1}$, Maria C. Cringoli ${ }^{1,2}{ }^{\mathbb{D}}$, Slavko Kralj ${ }^{3} \oplus$, Marina Kurbasic ${ }^{1}$, \\ Paolo Fornasiero ${ }^{1,2,4}$ (D), Paolo Pengo ${ }^{1, *}$ and Silvia Marchesan ${ }^{1,2, *(\mathbb{D})}$ \\ 1 Chemical \& Pharmaceutical Sciences Department, University of Trieste, 34127 Trieste, Italy; \\ tiziano.carlomagno@studenti.units.it (T.C.); mcringoli@units.it (M.C.C.); \\ marina.kurbasic@phd.units.it (M.K.); pfornasiero@units.it (P.F.) \\ 2 INSTM Trieste Research Unit, 34127 Trieste, Italy \\ 3 Materials Synthesis Department, Jožef Stefan Institute, 1000 Ljubljana, Slovenia; slavko.kralj@ijs.si \\ 4 ICCOM-CNR Trieste Research Unit, 34127 Trieste, Italy \\ * Correspondence: ppengo@units.it (P.P.); smarchesan@units.it (S.M.)
}

Academic Editor: Derek McPhee

Received: 9 June 2020; Accepted: 26 June 2020; Published: 30 June 2020

\begin{abstract}
Self-assembling peptides are attracting wide interest as biodegradable building blocks to achieve functional nanomaterials that do not persist in the environment. Amongst the many applications, biocatalysis is gaining momentum, although a clear structure-to-activity relationship is still lacking. This work applied emerging design rules to the heterochiral octapeptide sequence His-Leu- ${ }^{\text {D }}$ Leu-Ile-His-Leu- ${ }^{\mathrm{D}}$ Leu-Ile for self-assembly into nanofibrils that, at higher concentration, give rise to a supramolecular hydrogel for the mimicry of esterase-like activity. The peptide was synthesized by solid-phase and purified by HPLC, while its identity was confirmed by ${ }^{1} \mathrm{H}-\mathrm{NMR}$ and electrospray ionization (ESI)-MS. The hydrogel formed by this peptide was studied with oscillatory rheometry, and the supramolecular behavior of the peptide was investigated with transmission electron microscopy (TEM) analysis, circular dichroism (CD) spectroscopy, thioflavin T amyloid fluorescence assay, and attenuated total reflectance (ATR) Fourier-transform infrared (FT-IR) spectroscopy. The biocatalytic activity was studied by monitoring the hydrolysis of $p$-nitrophenyl acetate (pNPA) at neutral $\mathrm{pH}$, and the reaction kinetics followed an apparent Michaelis-Menten model, for which a Lineweaver-Burk plot was produced to determine its enzymatic parameters for a comparison with the literature. Finally, LC-MS analysis was conducted on a series of experiments to evaluate the extent of, if any, undesired peptide acetylation at the N-terminus. In conclusion, we provide new insights that allow gaining a clearer picture of self-assembling peptide design rules for biocatalysis.
\end{abstract}

Keywords: biocatalysis; fibrils; hydrogel; self-assembly; supramolecular material; peptide; amyloid; histidine; D-amino acids; esterase

\section{Introduction}

Enzymes have long been a great source of inspiration for organic chemists to develop new catalysts for industrial applications, as well as to achieve simple, low-cost mimetics that display activity in water and that are biodegradable, so that they do not persist in the environment [1]. One of the simplest approaches consists of the use of short peptides, since it is possible to directly incorporate the specific residues that perform the enzymatic catalysis in the amino-acid sequence. Self-assembling peptides offer additional advantages, such as the possibility to create hydrophobic pockets that provide ideal environments for reactions to occur, as well as multivalency for improved performance, thanks to the spatial proximity of multiple functional groups. It is, thus, not surprising that the topic is widely reviewed [2-5]. 
In particular, hydrolases are a class of enzymes that are of high relevance for industrial applications and for organic synthesis; thus, they provide a good target for biomimicry. They include enzymes such as lipases and proteases, which are both widely studied and used. Typically, a biomimetic sequence contains a histidine (His) residue that is a common feature in the catalytic active site. Prins et al. developed elegant systems, whereby a short His-containing peptide self-assembled on the surface of gold nanoparticles, yielding efficient transesterification catalysis [6]. Subsequent studies confirmed that self-assembly is a prerequisite to achieve catalytic efficiency, which can be enhanced by the presence of serine (Ser) residues [7]. Furthermore, different peptides can be used to increase the system complexity and achieve a dynamic structure [8]. Divalent cations can also be useful additives to promote the activity of hydrolytic metallo-nanozymes [9]. Indeed, typical approaches to activate the His residue toward catalysis comprise either inclusion of Ser and/or aspartate (Asp) to reconstitute the hydrolase catalytic triad as described by Luisi et al. and many others, such as Ulijn and Matsui [10,11], as well as Guler et al. [12], or metal coordination usually featuring divalent zinc, as shown for instance in an elegant study by DeGrado and Korendovych [13]. Other ions were studied by Hamley and Banerjee, such as trivalent iron or divalent mercury [14]. Arginine (Arg) also proved to be a useful inclusion to enhance catalytic activity when featured on supramolecular systems based on peptides developed by Liu et al. $[15,16]$. As knowledge of supramolecular peptide biocatalysts increased, amino-acid sequences could be progressively shortened in a minimalistic approach down to, remarkably, the single amino acid phenylalanine when self-assembled in the presence of zinc ions as recently reported by Gazit et al. [17].

However, at present, it is still not possible to predict exactly the performance of a de novo designed peptide. Amongst the various approaches to achieve a self-assembling short peptide, an attractive strategy features the inclusion of both D- and L-amino acids at specific positions along a heterochiral sequence, whereby nanostructured hydrogels can be formed even with just three amino acids, while their homochiral isomers typically precipitate in water [18]. These supramolecular systems feature amphipathic assemblies, whereby the different stereoconfiguration allows displaying hydrophobic side chains on the same side of the peptide backbone $[19,20]$. This design was also successfully applied to His- ${ }^{D}$ Phe- ${ }^{D}$ Phe, which displayed biocatalytic activity only in the self-assembled form, although it formed hydrogels at the very high concentration of $50 \mathrm{mM}$, thus limiting its practical use [21]. To validate the design on longer and more diverse heterochiral sequences to achieve nanostructured functional materials, we designed the octapeptide His-Leu- ${ }^{D}$ Leu-Ile-His-Leu- ${ }^{D}$ Leu-Ile for this study. The sequence is devoid of phenylalanine, which is featured in all other gelling heterochiral unprotected peptides [18], to expand the sequence design. It is based on a tetramer sequence that features His as a catalytic site, as well as hydrophobic residues leucine (Leu) and isoleucine (Ile) that are expected to provide sufficient hydrophobicity for self-assembly in aqueous solutions. The choice for an octapeptide allows for a more appropriate comparison with other biocatalysts that feature two His residues and a similar number of amino acids [13,15,22].

\section{Results and Discussion}

\subsection{Peptide Self-Assembly}

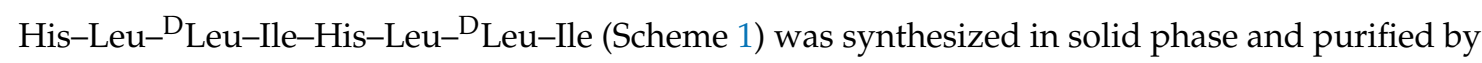
reverse-phase HPLC, following published procedures [20]. Peptide identity and purity was confirmed by ${ }^{1} \mathrm{H}-\mathrm{NMR}$ and electrospray ionization (ESI)-MS (see Supplementary Materials). Its hydrophobicity was evident in its limited water solubility at neutral $\mathrm{pH}$. Dissolution was possible at acidic $\mathrm{pH}$, whereby the peptide is present in its cationic form. A pH change to neutral was then used to trigger fibrillization, which, at higher concentrations, led to the formation of self-supportive hydrogels, with a minimum gelling concentration $(\mathrm{mgc})$ of $10 \mathrm{mM}$. The viscoelastic properties of the hydrogel were assessed by oscillatory rheometry (see Supplementary Materials). At mgc, the peptide gelled immediately and reached a $\mathrm{G}^{\prime}$ of $1 \mathrm{kPa}$, which remained stable over time. Frequency sweeps confirmed 
$\mathrm{G}^{\prime}>\mathrm{G}^{\prime \prime}$, with both values being independent of applied frequency, as expected for a stable hydrogel. Stress sweeps confirmed a linear viscoelastic region until $1 \mathrm{~Pa}$, with a gel-to-sol transition occurring above $10 \mathrm{~Pa}$.<smiles>CCC(C)[C@H](NC(=O)[C@H](CC(C)C)NC(=O)[C@H](CC(C)C)NC(=O)[C@H](CC(C)C)NC(=O)[C@H](Cc1cnc[nH]1)NC(=O)[C@H](CC(C)C)NC(=O)[C@H](N)Cc1cnc[nH]1)C(=O)O</smiles>

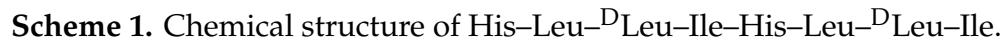

Transmission electron microscopy (TEM) analysis was, thus, performed to analyze the nanomorphology leading to the hydrogel at $\mathrm{mgc}$, as well as the presence of any nanostructure at lower concentrations (Figure 1). At $0.05 \mathrm{mM}$, only rare instances of short nanofibrils were noted, and the sample was mainly characterized by spherical morphologies suggesting peptide nucleation, which was likely driven by hydrophobicity (Figure 1a). At $0.1 \mathrm{mM}$, nanofibrils became evident, albeit spanning only a few hundred nanometers in length (Figure 1b). At concentrations $\geq 1 \mathrm{mM}$ (Figure 1c-e), samples revealed dense networks of homogeneously sized fibrils with length spanning several microns. Fibril diameter $(3.5 \mathrm{~nm})$ was unchanged across samples; occasionally, bundles of two, and rarely of three, nanofibrils were noted, with no significant difference across the concentrations tested (Figure $1 \mathrm{f}-\mathrm{h}$ ). Contrarily to other heterochiral amyloid peptides, no increase in hierarchical bundling was noted with increasing concentration, suggesting that the main difference between samples at 1, 5, or $10 \mathrm{mM}$ simply concerned the number of fibrils [19-21].

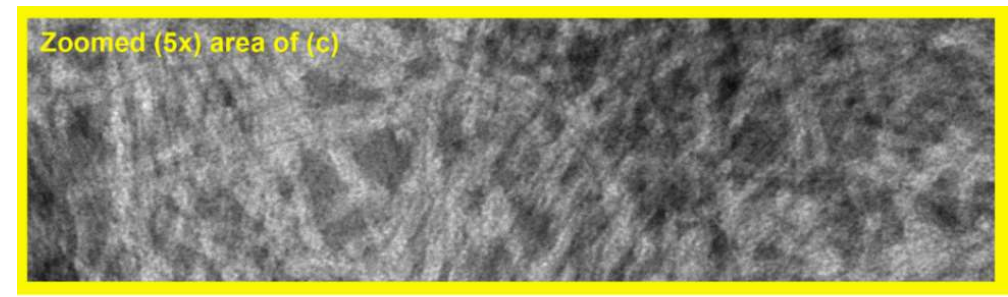

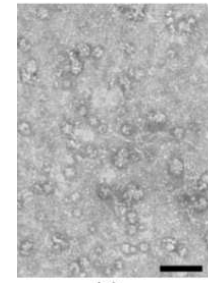

(a)

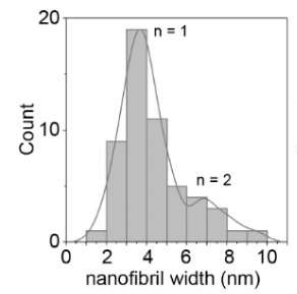

(f)

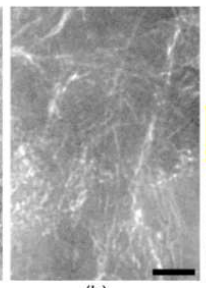

(b)

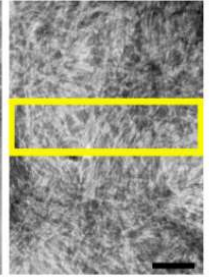

(c)

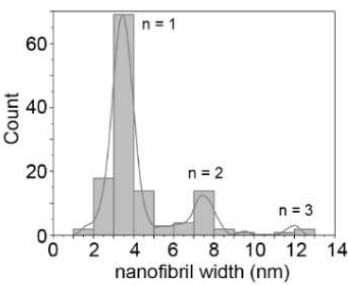

(g)
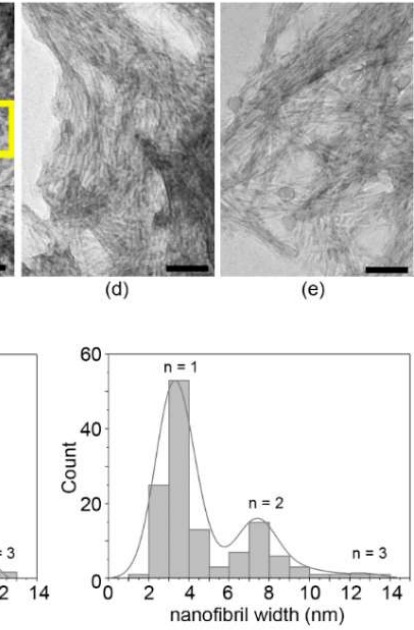

(h)

Figure 1. TEM analysis of peptide samples at various concentrations: (a) $0.05 \mathrm{mM}$; (b) $0.1 \mathrm{mM}$; (c) $1 \mathrm{mM}$; (d) $5 \mathrm{mM}$; (e) $10 \mathrm{mM}$. The yellow rectangle in (c) corresponds to the zoomed area (5X) shown above to assist the reader with fibril visualization. Nanofibril size distribution revealed consistent data over the concentrations tested, suggesting nanofibrils of approximately $3.5 \mathrm{~nm}$ width $(n=1)$, occasionally bundling in pairs $(n=2)$ or, rarely, in triplets $(n=3)$ : (f) $0.1 \mathrm{mM}(n=50) ;(\mathbf{g}) 1 \mathrm{mM}(n=130) ;(\mathbf{h}) 10 \mathrm{mM}$ $(n=130)$. Scale bar $=200 \mathrm{~nm}$ in $(\mathbf{a})$, and $100 \mathrm{~nm}$ in $(\mathbf{b}-\mathbf{e})$. 


\subsection{Peptide Secondary Structure}

TEM analysis suggested an amyloid nature for the octapeptide; therefore, thioflavin T was used to confirm this hypothesis. This is a dye that was shown to bind to $\beta$-sheet amyloid fibril surfaces; as a result of this interaction, the rotation between the benzothiazole and the benzene rings is impeded, leading to fluorescence [23]. Already at $0.1 \mathrm{mM}$, significant fluorescence was noted, with a non-linear increase at higher concentrations, as typically shown for amyloids (Figure 2a). Fluorescence appeared to plateau at the highest concentration tested, $10 \mathrm{mM}$, which corresponded to the mgc.

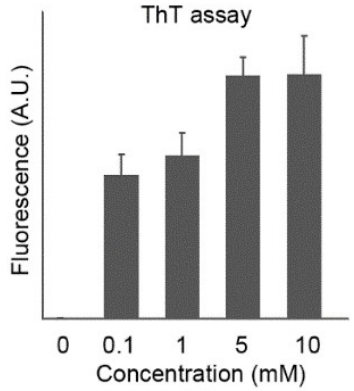

(a)

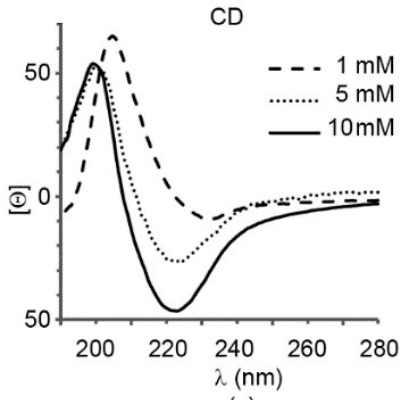

(c)

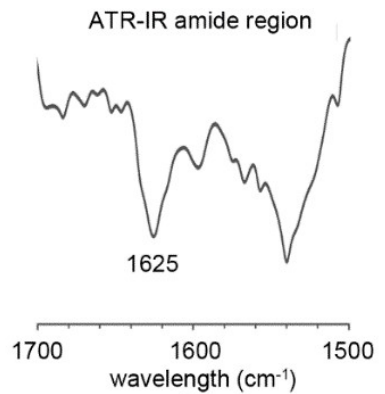

(b)

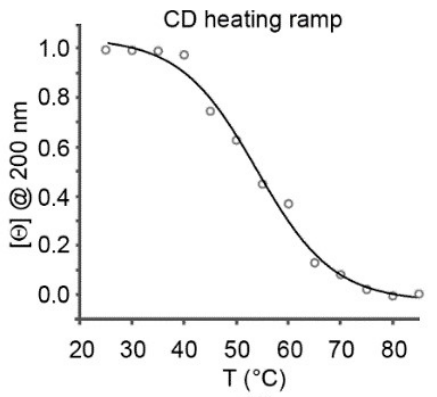

(d)

Figure 2. Peptide secondary structure. (a) Thioflavin T fluorescence assay; (b) attenuated total reflectance infrared (ATR-IR) amide region at $10 \mathrm{mM}$; (c) circular dichroism (CD) spectra; (d) CD heating ramp revealing a $\mathrm{T}_{\mathrm{m}}=54^{\circ} \mathrm{C}$ at $10 \mathrm{mM}$.

Attenuated total reflectance (ATR) infrared spectra displayed in the amide region a main signal at $1625 \mathrm{~cm}^{-1}$ that is diagnostic for amyloids (Figure 2b). Another major signal at $1540 \mathrm{~cm}^{-1}$ was due to the His imidazole ring [24], as well as the peak at $1568 \mathrm{~cm}^{-1}$. Furthermore, a minor peak at $1694 \mathrm{~cm}^{-1}$ suggested presence of the C-terminal carboxylic group in its neutral form [25], as already reported for other amyloids, whereby the supramolecular organization disfavored deprotonation [26-31].

Circular dichroism (CD) spectroscopy also confirmed a signature compatible with $\beta$-sheets, with a minimum at $225 \mathrm{~nm}$ and a maximum at $200 \mathrm{~nm}$ at the $\mathrm{mgc}$ (Figure 2c). The spectrum was similar at $5 \mathrm{mM}$, in agreement with the fluorescence data, although with a less intense $\beta$-sheet minimum. Lowering the concentration further to $1 \mathrm{mM}$ led to red-shifts at both peaks. Heating ramps from room temperature up to $85^{\circ} \mathrm{C}$ allowed monitoring the loss of the supramolecular structure, with a $\mathrm{T}_{\mathrm{m}}$ of $54{ }^{\circ} \mathrm{C}$ (Figure $2 \mathrm{~d}$ ), thus indicating that the gel at mgc displayed good stability.

\subsection{Biocatalytic Performance}

The esterase-like activity of the supramolecular structures was evaluated by monitoring the hydrolysis of 4-nitrophenyl acetate (pNPA). The product formed was 4-nitrophenol (pNP) that displayed a maximum of absorbance at $405 \mathrm{~nm}$. The catalysis was performed at different concentrations of peptide, $100 \mu \mathrm{M}, 1 \mathrm{mM}, 5 \mathrm{mM}$, and $10 \mathrm{mM}(\mathrm{mgc})$ at $\mathrm{pH}$ 7.0. Initial velocities $\left(\mathrm{V}_{\mathrm{i}}\right)$ for pNPA hydrolysis without catalyst (see Supplementary Materials) were subtracted from all samples. The absorbance 
curves fitted well as first-order kinetics, with the initial velocities $\left(\mathrm{V}_{\mathrm{i}}\right)$ being directly proportional to pNPA concentration (Table 1 and Supplementary Materials).

Table 1. Initial velocities $\left(\mathrm{V}_{\mathrm{i}}\right.$ expressed in $\left.\mathrm{mM} / \mathrm{s}\right)$ at different concentrations of 4-nitrophenyl acetate (pNPA) (0.2-1.0 mM) and different concentrations of peptide catalyst $(0.1,1,5$, and $10 \mathrm{mM})$.

\begin{tabular}{ccccc}
\hline [pNPA] & $\mathbf{0 . 1} \mathbf{~ m M}$ & $\mathbf{1 ~} \mathbf{~ M}$ & $\mathbf{5} \mathbf{~ m M}$ & $\mathbf{1 0} \mathbf{~} \mathbf{M}$ \\
\hline 0.2 & $6.25 \times 10^{-6}$ & $7.14 \times 10^{-5}$ & $1.10 \times 10^{-4}$ & $2.24 \times 10^{-4}$ \\
0.4 & $1.26 \times 10^{-5}$ & $1.31 \times 10^{-4}$ & $1.85 \times 10^{-4}$ & $4.32 \times 10^{-4}$ \\
0.6 & $1.87 \times 10^{-5}$ & $1.76 \times 10^{-4}$ & $4.48 \times 10^{-4}$ & $7.40 \times 10^{-4}$ \\
0.8 & $2.51 \times 10^{-5}$ & $2.60 \times 10^{-4}$ & $4.07 \times 10^{-4}$ & $9.30 \times 10^{-4}$ \\
1.0 & $3.13 \times 10^{-5}$ & $3.29 \times 10^{-4}$ & $5.68 \times 10^{-4}$ & $1.11 \times 10^{-3}$ \\
\hline $\mathrm{k}_{\text {obs }}$ & $1.63 \times 10^{-4}$ & $3.22 \times 10^{-4}$ & $5.72 \times 10^{-4}$ & $1.14 \times 10^{-3}$ \\
\hline
\end{tabular}

Figure 3a shows the trend of the apparent activation free energy $\left(\Delta G^{\ddagger}\right)$ of the reaction, which is proportional to $\log \left(\mathrm{k}_{\mathrm{obs}}\right)$. Catalysis occurred in the presence of supramolecular structures formed by peptide self-assembly.

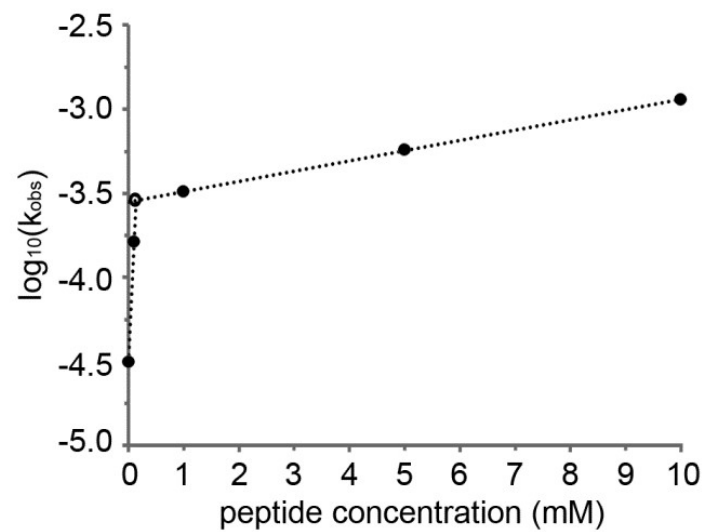

(a)

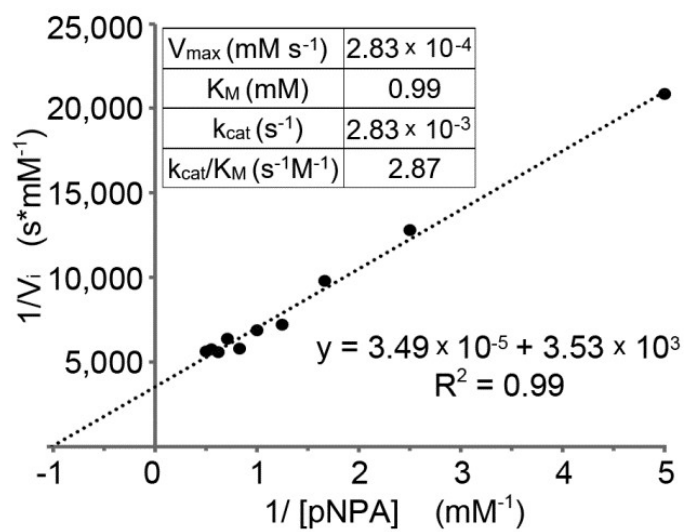

(b)

Figure 3. (a) $\log _{10}\left(\mathrm{k}_{\mathrm{obs}}\right)$ against peptide concentration; (b) Lineweaver-Burk plot with catalytic parameters (inset).

From the significant increase of $k_{\text {obs }}$ already at low concentrations of peptide, we inferred that amyloid nanofibrils, which were the active catalyst species, formed in sufficient quantity to significantly catalyze the reaction at a concentration of $\sim 0.1 \mathrm{mM}$ (intersection point in Figure 3a), confirming the results obtained by TEM analysis. At higher concentrations, a further increase of $\mathrm{k}_{\mathrm{obs}}$ was less dramatic, and it was mostly pertinent to the increase in surface area of nanofibrils present that increased with the concentration as shown by TEM micrographs. It is worth noting that catalytic tests performed with $10 \mathrm{mM}$ peptide were carried out in the hydrogel state, yet no evident detrimental effect due to limited diffusion was noted on the catalytic performance. We inferred that the soft nature of the hydrogel, having a $\mathrm{G}^{\prime}$ of $1 \mathrm{kPa}$ at the $\mathrm{mgc}$ of $10 \mathrm{mM}$, permitted the fast diffusion of small molecules throughout the sample.

To characterize this peptide with its catalytic parameters according to the Michaelis-Menten enzymatic model, it was necessary to collect a series of data points for substrate concentration significantly greater than catalyst concentration. Moreover, it was not possible to use high concentrations of pNPA, due to the saturation of the signal in short times and to dissolution problems in $\mathrm{MeOH}$. For this reason, $0.1 \mathrm{mM}$ was a peptide concentration suitable for this type of analysis. The data obtained, reported in the inset in Figure $3 b$, fitted well an apparent Michaelis-Menten function, and a Lineweaver-Burk plot was realized (Figure $3 b$ ) to extrapolate the value of maximum velocity $\left(\mathrm{V}_{\max }\right)$ and the Michaelis-Menten constant $\left(\mathrm{K}_{\mathrm{M}}\right)$ and, thus, calculate the turnover number $\left(\mathrm{k}_{\mathrm{cat}}\right)$. Finally, 
the ratio $\mathrm{k}_{\mathrm{cat}} / \mathrm{K}_{\mathrm{M}}$, which is an evaluation of the capacity of the peptide to catalyze this specific reaction, was obtained for a comparison against literature data (Table 2). For a meaningful comparison, peptide catalysts activated with zinc cations or with catalytic parameters derived at a very different $\mathrm{pH}$ were not included. Overall, the designed catalyst is within range of reported self-assembling peptide performance for ester hydrolysis, although it is clearly surpassed by the peptide amphiphile reported by Guler and Stupp [22]. Other peptides, of similar length to the one of this study (7-mers), also showed very efficient performance; however, their catalytic parameters were assessed under different conditions, i.e., with zinc dication as an activator, and at $\mathrm{pH} 8.0$ [13].

Table 2. Comparison of catalytic performance with literature data on short peptides without $\mathrm{Zn}^{2+}$.

\begin{tabular}{|c|c|c|c|c|}
\hline Peptide Sequence & Number of His & $\mathrm{pH}$ & $\begin{array}{c}\mathbf{k}_{\mathrm{cat}} / \mathbf{K}_{\mathbf{M}} \\
\left(\mathrm{s}^{-1} \mathbf{M}^{-1}\right)\end{array}$ & Reference \\
\hline cyclo(HF) + cyclo(CF) & 1 & 7.5 & 0.09 & [32] \\
\hline HSGQQKFQFQFEQQ & 1 & 7.4 & 0.09 & [15] \\
\hline cyclo(HF) + cyclo(CV) & 1 & 7.3 & 0.13 & [32] \\
\hline $\begin{array}{c}\text { HSGQQKFQFQFEQQ + } \\
\text { RSGQQKFQFQFEQQ }\end{array}$ & 1 & 7.4 & 0.15 & [15] \\
\hline $\operatorname{cyclo}(\mathrm{HF})+\operatorname{cyclo}(\mathrm{CL})$ & 1 & 7.4 & 0.2 & [32] \\
\hline HL $^{\mathrm{D}}$ LIHL $^{\mathrm{D}} \mathrm{LI}$ & 2 & 7.0 & 2.9 & This work \\
\hline $\mathrm{H}_{2} \mathrm{KLLLAAA}\left(\mathrm{N} \varepsilon\right.$-palmytoyl)K- $\mathrm{NH}_{2}$ & 2 & 7.4 & 20 & [22] \\
\hline
\end{tabular}

The free amino group at the N-terminus of the peptide could potentially act as a nucleophile, leading to peptide acetylation. To verify this hypothesis, further experiments were carried out at different concentrations of peptide and substrate, and the reactions were analyzed by LC-MS. The ratio of concentrations investigated went from an excess of peptide to an excess of substrate, and the percentage of pNPA converted by nucleophilic acyl substitution $\left(\mathrm{S}_{\mathrm{N}} \mathrm{Ac}\right)$ was calculated and is reported in Table 3. In all cases, regardless of the conditions tested, the vast majority of pNPA underwent the desired catalyzed hydrolysis, rather than $\mathrm{S}_{\mathrm{N}}$ Ac. From an analysis of the percentages of pNPA hydrolyzed by nucleophilic acyl substitution, it is possible to notice that, upon increasing [pNPA] compared to the peptide, there was a decrease in the quantity of substrate converted by nucleophilic attack. This was due to the reduction of probability to collide and react with the amino group. Consequently, the amount of pNPA hydrolyzed by water, with peptide-mediated catalysis, increased. On the other hand, at higher concentrations of peptide, the quantity of pNPA that reacted with the amino group was greater, because of the increased competitiveness of the acetylation compared to hydrolysis. A potential strategy to address this issue could be peptide cyclization or acetylation. Unfortunately, at high amounts of acetylated peptide, insoluble aggregates were noted that required dissolution by dimethyl sulfoxide (DMSO) prior to LC-MS analysis. This observation suggested that the octapeptide acetylation disrupted self-assembly. Therefore, other design strategies, other than acetylation, will be needed to enhance these systems.

Table 3. LC-MS analysis to verify the extent of amine-mediated acetylation

\begin{tabular}{ccccc}
\hline $\begin{array}{c}\text { [Peptide] } \\
(\mathbf{m M})\end{array}$ & $\begin{array}{c}\text { [pNPA] } \\
(\mathbf{m M})\end{array}$ & $\begin{array}{c}\text { \% Ac-Peptide } \\
\left(\mathbf{S}_{\mathbf{N}} \mathbf{A c}\right)\end{array}$ & $\begin{array}{c}\text { \% } \mathbf{p N P A} \\
\left(\mathbf{S}_{\mathbf{N}} \mathbf{A c}\right)\end{array}$ & $\begin{array}{c}\% \text { pNPA } \\
(\text { Catalysis })\end{array}$ \\
\hline 1.0 & 0.2 & 7 & 35 & 65 \\
1.0 & 1.0 & 26 & 26 & 74 \\
0.1 & 0.4 & 36 & 9 & 91 \\
0.1 & 1.0 & 64 & 6 & 94 \\
0.1 & 2.0 & 81 & 4 & 96 \\
\hline
\end{tabular}


In conclusion, this work described a nanostructured hydrogel in phosphate buffer of an octapeptide that displayed esterase-like catalytic activity in the assembled state. Peptide design based on heterochirality was successful, showing that the emerging rules for the correct positioning of D-amino acids along hydrophobic short sequences can be extended beyond tripeptides [20]. Nanofibrils were formed to a large extent already at $0.1 \mathrm{mM}$, while the minimum gelling concentration corresponded to $10 \mathrm{mM}$. Catalytic activity followed Michaelis-Menten kinetics, and the performance was within range of reported short peptides without zinc activation, which is relevant to phosphate-buffered systems that are incompatible with zinc, as zinc phosphate would precipitate out of solution. Overall, this study expanded our understanding of this kind of peptide catalyst, while further improvements will be needed to achieve very efficient catalysts with this design.

\section{Materials and Methods}

\subsection{Materials}

2-Chlorotrityl resin, O-benzotriazole- $N, N, N, N^{\prime}$-tetramethyl-uronium-hexafluoro-phosphate (HBTU), and Fmoc-protected amino acids were purchased from GL Biochem (Shanghai, China) Ltd. All solvents were purchased of analytical grade from Merck. Piperidine, trifluoroacetic acid (TFA), $\mathrm{N}, \mathrm{N}$-diisopropyl ethyl amine (DIPEA), and triisopropyl silane (TIPS) were from Acros (Milan, Italy). Sodium dihydrogen phosphate and disodium hydrogen phosphate were from BDH AnalaR (Milan, Italy). High-purity Milli-Q-water (MQ water) with a resistivity greater than $18 \mathrm{M} \Omega \cdot \mathrm{cm}$ was obtained from an in-line Millipore RiOs/Origin system.

\subsection{Peptide Synthesis and Characterisation}

The peptide was synthesized in solid phase on chlorotrityl resin, using Fmoc protection and HBTU activation, followed by purification using reverse-phase HPLC, using standard procedures [20]. ${ }^{1} \mathrm{H}-\mathrm{NMR}$ spectra were recorded at $400 \mathrm{MHz}$ on a Varian Innova Instrument with chemical shift reported as ppm (in DMSO or MeCN with tetramethylsilane as internal standard). ESI-MS spectra were recorded on an Agilent 6120 single quadrupole LC-MS system.

\subsection{Self-Assembly Protocol}

The peptide was dissolved in a sodium dihydrogen phosphate solution $(0.2 \mathrm{M})$ and brought to $\mathrm{pH} 2.0$ with the addition of $1 \mathrm{M} \mathrm{HCl}$ (to reach overall $85 \%$ of final volume), as well as with the aid of sonication in an ultrasound bath (Branson, Milan, Italy). Self-assembly was triggered by the addition of $1 \mathrm{M} \mathrm{NaOH}$ to achieve the desired final concentration at $\mathrm{pH}$ 7.0.

\subsection{Oscillatory Rheometry}

Dynamic time sweep rheological analysis was conducted on a Malvern Kinexus Ultra Plus Rheometer (Alfatest, Milan, Italy) with a 20-mm stainless-steel parallel plate geometry. The temperature was maintained at $25{ }^{\circ} \mathrm{C}$ using a Peltier temperature controller. Samples were prepared in situ and immediately analyzed with a gap of $1 \mathrm{~mm}$. Time sweeps were recorded using a frequency of $1 \mathrm{~Hz}$ and a controlled stress of $0.50 \mathrm{~Pa}$. Frequency sweeps were recorded using a controlled stress of $0.50 \mathrm{~Pa}$, and then stress sweeps were recorded using a frequency of $1 \mathrm{~Hz}$.

\subsection{Transmission Electron Microscopy (TEM)}

The nanostructure morphology of the peptide was determined at $50 \mu \mathrm{M}, 100 \mu \mathrm{M}, 1 \mathrm{mM}, 5 \mathrm{mM}$, and $10 \mathrm{mM}$ with a transmission electron microscope (TEM). Firstly, $5 \mu \mathrm{L}$ of the peptide solution/hydrogel was poured on copper-lacey carbon-coated 300-mesh grids, while a TEM grid was exposed for 6 min under ultraviolet (UV) ozone cleaner just before material deposition. After 1 min of adsorption, the excess was drawn off, and $5 \mu \mathrm{L}$ of a $2 \%$ aqueous potassium phosphotungstate at $\mathrm{pH} 7.2$ was poured on the grids. Grids were air-dried until needed, and TEM images were acquired using a 
Jeol JEM 2100 instrument at $100 \mathrm{kV}$. Images were analyzed using the free software ImageJ (Wayne Rasband, Madison, FIJI), and the measurements were performed manually ( $n=130$ for $1 \mathrm{mM}$ and $10 \mathrm{mM}$ samples; $n=50$ for $0.1 \mathrm{mM}$ sample because fibrils were fewer due to the significantly lower peptide concentration).

\subsection{Thioflavin T Fluorescence}

Fluorescence emission was measured with an Infinite M1000 Pro TECAN plate reader, using an excitation wavelength of $446 \mathrm{~nm}$ and an emission wavelength of $484 \mathrm{~nm}$. Firstly, $120 \mu \mathrm{L}$ of the peptide solutions and $30 \mu \mathrm{L}$ of ThT solution ( $24 \mu \mathrm{M}$ in $20 \mathrm{mM}$ glycine- $\mathrm{NaOH} \mathrm{pH} \mathrm{7.5,} \mathrm{filtered} \mathrm{with} \mathrm{a} 0.2-\mu \mathrm{m}$ filter) were poured in a $96-\mathrm{U}$ bottom black polystyrene microplate, and fluorescence was measured after $15 \mathrm{~min}$.

\subsection{ATR-IR Spectroscopy}

The infrared (IR) spectra were recorded with a Jasco 4700 Fourier-transform (FT)-IR, equipped with an ATR Pro One. A drop of the hydrogel was placed on a silicon wafer, and then dried under vacuum. Spectra were acquired with $1-\mathrm{cm}^{-1}$ resolution.

\subsection{Circular Dichroism (CD) Spectroscopy}

A 0.1-mm quartz cell was used on a Jasco J815 Spectropolarimeter, with 1-s integrations, one accumulation, and a step size of $1 \mathrm{~nm}$ with a bandwidth of $1 \mathrm{~nm}$ over a range of wavelengths from 190 to $280 \mathrm{~nm}$ at $20^{\circ} \mathrm{C}$. Samples were prepared as indicated above in Section 3.3 in the CD cell, and spectra were immediately recorded. Shown spectra are the average of at least five measurements. Heating ramps were recorded from $25^{\circ} \mathrm{C}$ to $85^{\circ} \mathrm{C}$, with $5^{\circ} \mathrm{C}$ intervals.

\subsection{Biocatalysis}

The esterase activity of the peptide was evaluated by following the hydrolysis of 4-nitrophenyl acetate (pNPA). The formation of the product was analyzed with an Infinite M1000 Pro TECAN plate reader at a wavelength of $405 \mathrm{~nm}$. The reaction was monitored at $10 \mathrm{mM}, 5 \mathrm{mM}, 1 \mathrm{mM}$, and $0.1 \mathrm{mM}$ of peptide and $1.0 \mathrm{mM}, 0.8 \mathrm{mM}, 0.6 \mathrm{mM}, 0.4 \mathrm{mM}$, and $0.2 \mathrm{mM}$ of pNPA ( $n=6$ for each condition). In each well, $90 \mu \mathrm{L}$ of peptide solution at $\mathrm{pH} 7.0$ and $10 \mu \mathrm{L}$ of pNPA in MeOH were added. A Michaelis-Menten plot and a Lineweaver-Burk plot were realized using a concentration of pNPA from $0.2 \mathrm{mM}$ to $2 \mathrm{mM}$ and $0.1 \mathrm{mM}$ of peptide.

Supplementary Materials: The following are available online: spectroscopic data, rheometry data, biocatalysis data.

Author Contributions: Conceptualization, P.P. and S.M.; investigation, T.C., S.K., and M.K.; resources, P.F. and S.M.; supervision, M.C.C., M.K., P.F., P.P., and S.M. All authors have read and agreed to the published version of the manuscript.

Funding: This research was funded by MIUR through the SIR program, "HOT-SPOT" project, personal research grant n. RBSI14A7PL to S.M. and by the Slovenian Research Agency (ARRS) through the core funding No. P2-0089 and project No. J1-7302.

Acknowledgments: We acknowledge the CENN Nanocenter (Slovenia) for the access to electron microscopy.

Conflicts of Interest: The authors declare no conflicts of interest.

\section{References}

1. Choi, J.M.; Han, S.S.; Kim, H.S. Industrial applications of enzyme biocatalysis: Current status and future aspects. Biotechnol. Adv. 2015, 33, 1443-1454. [CrossRef] [PubMed]

2. Duncan, K.L.; Ulijn, R.V. Short Peptides in Minimalistic Biocatalyst Design. Biocatalysis 2015, $2015,67-81$. [CrossRef]

3. Zozulia, O.; Dolan, M.A.; Korendovych, I.V. Catalytic peptide assemblies. Chem. Soc. Rev. 2018, 47, 3621-3639. [CrossRef] 
4. Singh, N.; Kumar, M.; Miravet, J.F.; Ulijn, R.V.; Escuder, B. Peptide-Based Molecular Hydrogels as Supramolecular Protein Mimics. Chem. Eur. J. 2017, 23, 981-993. [CrossRef]

5. Maeda, Y.; Makhlynets, O.V.; Matsui, H.; Korendovych, I.V. Design of Catalytic Peptides and Proteins Through Rational and Combinatorial Approaches. Ann. Rev. Biomed. Eng. 2016, 18, 311-328. [CrossRef]

6. Zaramella, D.; Scrimin, P.; Prins, L.J. Self-Assembly of a Catalytic Multivalent Peptide-Nanoparticle Complex. J. Am. Chem. Soc. 2012, 134, 8396-8399. [CrossRef] [PubMed]

7. Zaramella, D.; Scrimin, P.; Prins, L.J. Catalysis of Transesterification Reactions by a Self-Assembled Nanosystem. Int. J. Mol. Sci. 2013, 14, 2011-2021. [CrossRef] [PubMed]

8. Garcia Martin, S.; Prins, L.J. Dynamic nanoproteins: Self-assembled peptide surfaces on monolayer protected gold nanoparticles. Chem. Commun. 2016, 52, 9387-9390. [CrossRef]

9. Mancin, F.; Prins, L.J.; Pengo, P.; Pasquato, L.; Tecilla, P.; Scrimin, P. Hydrolytic metallo-nanozymes: From micelles and vesicles to gold nanoparticles. Molecules 2016, 21, 1014. [CrossRef] [PubMed]

10. Gorlero, M.; Wieczorek, R.; Adamala, K.; Giorgi, A.; Schininà, M.E.; Stano, P.; Luisi, P.L. Ser-His catalyses the formation of peptides and PNAs. FEBS Lett. 2009, 583, 153-156. [CrossRef]

11. Maeda, Y.; Javid, N.; Duncan, K.; Birchall, L.; Gibson, K.F.; Cannon, D.; Kanetsuki, Y.; Knapp, C.; Tuttle, T.; Ulijn, R.V.; et al. Discovery of Catalytic Phages by Biocatalytic Self-Assembly. J. Am. Chem. Soc. 2014, 136, 15893-15896. [CrossRef] [PubMed]

12. Gulseren, G.; Khalily, M.A.; Tekinay, A.B.; Guler, M.O. Catalytic supramolecular self-assembled peptide nanostructures for ester hydrolysis. J. Mater. Chem. B 2016, 4, 4605-4611. [CrossRef] [PubMed]

13. Rufo, C.M.; Moroz, Y.S.; Moroz, O.V.; Stöhr, J.; Smith, T.A.; Hu, X.; DeGrado, W.F.; Korendovych, I.V. Short peptides self-assemble to produce catalytic amyloids. Nat. Chem. 2014, 6, 303-309. [CrossRef]

14. Gayen, K.; Basu, K.; Bairagi, D.; Castelletto, V.; Hamley, I.; Banerjee, A. An amino acid based metallo-hydrogel that acts like an esterase. ACS Appl. Bio Mater. 2018, 1, 1717-1724. [CrossRef]

15. Zhang, C.; Xue, X.; Luo, Q.; Li, Y.; Yang, K.; Zhuang, X.; Jiang, Y.; Zhang, J.; Liu, J.; Zou, G.; et al. Self-Assembled Peptide Nanofibers Designed as Biological Enzymes for Catalyzing Ester Hydrolysis. ACS Nano 2014, 8, 11715-11723. [CrossRef]

16. Huang, Z.; Guan, S.; Wang, Y.; Shi, G.; Cao, L.; Gao, Y.; Dong, Z.; Xu, J.; Luo, Q.; Liu, J. Self-assembly of amphiphilic peptides into bio-functionalized nanotubes: A novel hydrolase model. J. Mater. Chem. B 2013, 1, 2297-2304. [CrossRef]

17. Makam, P.; Yamijala, S.S.R.K.C.; Tao, K.; Shimon, L.J.W.; Eisenberg, D.S.; Sawaya, M.R.; Wong, B.M.; Gazit, E. Non-proteinaceous hydrolase comprised of a phenylalanine metallo-supramolecular amyloid-like structure. Nat. Catal. 2019, 2, 977-985. [CrossRef]

18. Cringoli, M.C.; Bellotto, O.; De Zorzi, R.; Vargiu, A.V.; Marchesan, S. Self-Assembling L-D-L Tripeptides Dance the Twist. Synlett 2019, 434-438. [CrossRef]

19. Vargiu, A.V.; Iglesias, D.; Styan, K.; Waddington, L.; Easton, C.; Marchesan, S. Design of a hydrophobic tripeptide that self-assembles into amphiphilic superstructures forming a hydrogel biomaterial. Chem. Commun. 2016, 52, 5912-5915. [CrossRef]

20. Garcia, A.M.; Iglesias, D.; Parisi, E.; Styan, K.E.; Waddington, L.J.; Deganutti, C.; De Zorzi, R.; Grassi, M.; Melchionna, M.; Vargiu, A.V.; et al. Chirality Effects on Peptide Self-Assembly Unraveled from Molecules to Materials. Chem 2018, 4, 1862-1876. [CrossRef]

21. Garcia, A.M.; Kurbasic, M.; Kralj, S.; Melchionna, M.; Marchesan, S. A biocatalytic and thermoreversible hydrogel from a histidine-containing tripeptide. Chem. Commun. 2017, 53, 8110-8113. [CrossRef] [PubMed]

22. Guler, M.O.; Stupp, S.I. A Self-Assembled Nanofiber Catalyst for Ester Hydrolysis. J. Am. Chem. Soc. 2007, 129, 12082-12083. [CrossRef] [PubMed]

23. Amdursky, N.; Erez, Y.; Huppert, D. Molecular rotors: What lies behind the high sensitivity of the thioflavin-T fluorescent marker. Acc. Chem. Res. 2012, 45, 1548-1557. [CrossRef] [PubMed]

24. Matsuyama, S.; Kinugasa, S.; Tanabe, K.; Tamura, T. Spectral Database for Organic Compunds. SDBS. Available online: https://sdbs.db.aist.go.jp/sdbs/cgi-bin/landingpage?sdbsno=1051 (accessed on 22 June 2020).

25. Mesu, J.G.; Visser, T.; Soulimani, F.; Weckhuysen, B.M. Infrared and Raman spectroscopic study of pH-induced structural changes of 1-histidine in aqueous environment. Vibr. Spectrosc. 2005, 39, 114-125. [CrossRef] 
26. Garcia, A.M.; Lavendomme, R.; Kralj, S.; Kurbasic, M.; Bellotto, O.; Cringoli, M.C.; Semeraro, S.; Bandiera, A.; De Zorzi, R.; Marchesan, S. Self-Assembly of an Amino Acid Derivative into an Antimicrobial Hydrogel Biomaterial. Chem. Eur. J. 2020, 26, 1880-1886. [CrossRef]

27. Cross, E.R.; Adams, D.J. Probing the self-assembled structures and pKa of hydrogels using electrochemical methods. Soft Matter 2019, 15, 1522-1528. [CrossRef]

28. Tena-Solsona, M.; Nanda, J.; Díaz-Oltra, S.; Chotera, A.; Ashkenasy, G.; Escuder, B. Emergent Catalytic Behavior of Self-Assembled Low Molecular Weight Peptide-Based Aggregates and Hydrogels. Chem. Eur. J. 2016, 22, 6687-6694. [CrossRef]

29. Chen, L.; Revel, S.; Morris, K.; C. Serpell, L.; Adams, D.J. Effect of Molecular Structure on the Properties of Naphthalene-Dipeptide Hydrogelators. Langmuir 2010, 26, 13466-13471. [CrossRef] [PubMed]

30. Rodríguez-Llansola, F.; Escuder, B.; Miravet, J.F. Switchable Perfomance of an L-Proline-Derived Basic Catalyst Controlled by Supramolecular Gelation. J. Am. Chem. Soc. 2009, 131, 11478-11484. [CrossRef] [PubMed]

31. Tang, C.; Smith, A.M.; Collins, R.F.; Ulijn, R.V.; Saiani, A. Fmoc-diphenylalanine self-assembly mechanism induces apparent pKa shifts. Langmuir 2009, 25, 9447-9453. [CrossRef] [PubMed]

32. Kleinsmann, A.J.; Nachtsheim, B.J. A minimalistic hydrolase based on co-assembled cyclic dipeptides. Org. Biomol. Chem. 2020, 18, 102-107. [CrossRef] [PubMed]

Sample Availability: Samples of the peptide are available from the authors. 